\title{
PENINGKATAN KETERAMPILAN BERBICARA BAHASA INGGRIS MELALUI MEDIA FILM
}

\author{
Wardah Hanafiah \\ Jurusan Teknik Mesin, Politeknik Negeri Jakarta \\ E-mail: wardah.hanafiah@mesin.pnj.ac.id
}

\begin{abstract}
Abstrak
Penelitian ini bertujuan untuk mengetahui proses dan hasil peningkatan keterampilan berbicara bahasa Inggris menggunakan media belajar film. Film sebagai media belajar sangat disukai oleh mahasiswa sehingga memudahkan mahasiswa berinteraksi. Metode penelitian menggunakan penelitian tindakan. Proses pengumpulan data adalah observasi, catatan harian, dokumentasi dan tes. Proses validasi data penelitian dilakukan selama proses kegiatan tindakan dan hasil yang diperoleh serta melibatkan kolaborator. Hasil penelitian menunjukkan media belajar film memberikan dampak yang positif terhadap peningkatan keterampilan berbicara bahasa Inggris. Hal ini disebabkan karena penerapan media belajar film menjadi sangat menyenangkan. Nilai rata-rata dari siklus pertama ke siklus kedua sampai siklus ketiga mengalami peningkatan yang cukup signifikan. Nilai rata-rata siklus 1 adalah 62,2. Nilai rata-rata siklus 2 adalah 71,2. Nilai rata-rata siklus 3 ada;ah 80,5.
\end{abstract}

Kata kunci: Bahasa Inggris, Berbicara, Film, Media Belajar

\section{PENDAHULUAN}

Pembelajaran bahasa Inggris bagi mahasiswa khususnya bagi mahasiswa yang bukan jurusan bahasa Inggris masih menganggap sulit. Seperti bagi mahasiswa jurusan teknik mesin yang notabenenya belajar bahasa Inggris sebagai pembelajaran pendukung mata kuliah keahlian yang ditetapkan pada konsep pembelajaran untuk tujuan khusus, mereka masih sulit ketika diminta berbicara atau menyampaikan pendapat menggunakan bahasa Inggris. Hal ini disebabkan karena bahasa Inggris memang tidak digunakan sebagai bahasa sehari-hari.

Dari hasil observasi awal diketahui bahwa kesulitan yang utama dalam berbicara bahasa Inggris bagi mahasiswa jurusan Teknik Mesin adalah pengucapan yang masih belum tepat, penguasaan kosakata yang masih sedikit, tingkat motivasi yang rendah, dan penguasaan tata bahasa yang masih rendah. Padahal kosakata dan tata bahasa membantu para siswa untuk berbicara dengan lancar. Seperti yang telah dibuktikan oleh Kitagaki (2013) bahwa Menghafal kalimat bahasa Inggris memiliki efek pada peningkatan keterampilan berbicara. Artinya bahwa memorization memiliki peran yang penting dalam keterampilan berbicara bahasa Inggris. Hal ini disebabkan berbicara merupakan kemampuan yang mengharusnya setiap orang untuk berinteraksi dengan orang lain yang melibatkan pengetahuan ataupun keterampilan linguistik.

Hal ini sejalan dengan yang disampaikan Richards \& Renandya (2002), kemampuan untuk berbicara bahasa kedua atau bahasa asing merupakan tujuan yang kompleks. Yang harus dipahami adalah hakikat apa yang telribat dalam proses tersebut. Untuk memulai hal tersebut, berbicara digunakan untuk banyak tujuan yang berbeda dan tiap tujuan melibatkan keterampilan yang berbeda. Pembelajaran berbicara membutuhkan keterampilan lainnya seperti menyimk atau mendengarkan. 
Karena informasi yang telah didengar menjadi pengetahuan yang bisa digunakan untuk memperkaya informasi yang disampaikan dalam bahasa lisan.

Pembelajaran berbicara bahasa kedua dapat diintegrasikan ke dalam berbagai jenis keterampilan bahasa. Salah satu opsi yang paling umum adalah menggabungkan pengajaran berbicara dan mendengarkan, atau berbicara dan membaca, di mana peserta didik mendiskusikan materi konten mereka dalam kelompok besar atau kecil atau menyajikan laporan lisan. Mengajar berbicara juga dapat dimasukkan dengan menulis ketika tugas instruksional termasuk produksi lisan dan tulisan. Berbicara bahasa kedua dapat dicampur dengan pelafalan, pragmatik, dan belajar tentang budaya. Mengajarnya paling sering diintegrasikan dengan keterampilan bahasa yang terkait erat seperti mendengarkan, yang terjadi pada tahap awal: peserta didik mempraktikkan keterampilan reseptif sebelum beralih ke produksi bahasa lisan, yang dibangun di atas pemahaman mendengarkan (Hinkel, 2018).

Masalah lain yang ditemukan adalah penerapan media belajar yang kurang maksimal. Selama ini media belajar yang digunakan belum mengarah pada keragaman media belajar yang disukai oleh mahasisw, seperti film. Padahal banyak penelitian yang telah membuktikan. Makalah Bonsignori (2018) ini menyajikan hasil dari proyek yang dilakukan di Pusat Bahasa Universitas Pisa dalam kemitraan dengan Pusat Bahasa Universitas California di Berkeley untuk berkolaborasi dalam pengembangan Perpustakaan Klip Film Bahasa Asing (LFLFC), yang bertujuan untuk mempromosikan pembelajaran bahasa dan budaya melalui film. Pilihan potongan klip dari film dan serial TV sengaja dipilih karena berkaitan dengan genre yang berbeda dan ditandai dengan penggunaan bahasa Inggris dalam domain khusus (mis., Hukum, politik, ekonomi, pariwisata, dan kedokteran). Mereka digunakan untuk menunjukkan bagaimana berbagai sumber daya semiotik bekerja bersama untuk membangun makna dalam ESP dan bagaimana mereka dapat menyediakan alat yang berguna untuk penelitian dan pengajaran dalam konteks ESP.

Berdasarkan paparan tersebut diketahuibahwa media pembelajaran yang tepat harus disesuaikan dengan kebutuhan mahasiswa dalam belajar suatu mata kuliah. Oleh karena itu, seorang pengajar seharusnya mengetahui lebih jelas kebutuhan media, metode ataupun materi yang sesuai dengan tujuan yang ingin dicapai ataupun dikuasai oleh mahasiswa. Permasalahan dalam penelitian ini merujuk pada cara seorang guru memanfaatkan teknologi sebagai media belajar bahasa Inggris di kelas jurusan Teknik Mesin. Konsep pembelajaran yang dilakukan dengan praktek langsung dan mengeksplorasi pola berpikir mahasiswa karena harus menyajikan isi dari film yang telah ditonton. Dengan demikian, rumusan masalah dalam penelitian ini adalah Bagaimana proses peningkatan keterampilan berbicara bahasa Inggris menggunakan media belajar film di Jurusan Teknik Mesin Politeknik Negeri Jakarta?

\section{Kajian Teoritik \\ Media Belajar Film}

Mengajar bahasa Inggris melalui film adalah salah satu metode yang lebih baik untuk pemindahan budaya, singkat dari pembelajar di luar negeri. Akan tetapi, untuk memastikan siswa mempelajari materi dan menyimpannya, sejumlah waktu dan pikiran perlu diinvestasikan ke dalam pelajaran. Mahasiswa tahun pertama mengalami banyak aturan dan keterampilan baru dan membutuhkan tugas yang solid yang dibuat dengan baik. Rata-rata 2-3 jam diberikan untuk menciptakan pelajaran dan kegiatan yang sesuai dengan kemampuan siswa dan menyampaikan pembelajaran yang 
diinginkan (Brown, 2010). Persepsi siswa terhadap film dan media streaming sangat kuat. Ini berarti bahwa mereka tertarik untuk belajar menulis melalui film dan media streaming dan memberikan konteks positif dalam pembelajaran. Media ini memberikan keuntungan untuk meningkatkan kemampuan menulis siswa dan menunjukkan strategi belajar yang berbeda tanpa rasa bosan (meinawati, 2015). Dariekdua pendapat etrsbeut disimpulkan bahwa film memiliki daya tarik yang baik untuk para mahasiswa belajar bahasa asing baik keterampilan menulis maupun berbicara.

Materi video dapat digunakan sebagai input materi otentik dan sebagai alat motivasi. Secara umum, siswa menemukan pengalaman menggunakan materi video menjadi menarik, relevan, bermanfaat dan agak memotivasi di kelas. Guru dan siswa dapat terlibat dalam caracara kreatif untuk memasukkan materi video yang berbeda dalam berbagai kegiatan kelas untuk meningkatkan hasil belajar dan memberikan lingkungan kelas yang positif. Namun, menggunakan video di kelas untuk memotivasi siswa bisa menggunakan situs web sebagai media untuk belajar bahasa Inggris di luar kelas dan mengembangkan beberapa tingkat otonomi pelajar masih kurang jelas. Video dapat membantu mempromosikan pemahaman mendengarkan pembelajar bahasa juga (Bajrami \& Ismaili, 2016).

Dari hasil penelitian yang telah dipaparkan disimpulkan bahwa film ataupun video menjadi media belajar yang sangat tepat untuk menghilangkan kebosanan dalam belajar bahasa Inggris. Dalam penelitian ini, mahasiswa belajar berbicara melalui film yang ditayangkan, kemudian mahasiswa harus mempresentasikan isi film tersebut. Film yang digunakana adalah film pendek seperti film documenter yang diambil dari Youtube.

\section{Pembelajaran Keterampilan Berbicara}

Proses pembelajaran berbicara dalam pembelajaran bahasa asing menuntut siswa untuk memiliki pengetahuan kosakata, pemahaman tata bahasa, semantic dan pragmatic. Hal ini disebabkan karena kemampuan berbicara menuntut adanya interaksi sosial yang tepat dalam berkomunikasi agar efektif (Richards \& Renandya, 2002). Pendapat berbeda disampaikan oleh Jones, “ In speaking and listening we tend to be getting something done, exploring ideas, working out some aspect of the world, or simply being together. In writing, we may be creating a record, committing events or moments to paper."(Richards, 2008). Dari pendapat Jones disimpulkan bahwa dalam berbicara dan mendengarkan kita cenderung menyelesaikan sesuatu, mengeksplorasi ide-ide, mengerjakan beberapa aspek dunia, atau sekadar bersama. Secara tertulis, kami mungkin membuat catatan, melakukan peristiwa atau saat-saat di atas kertas.

Menurut Halliday bahwa dalam bahasa lisan atau proses berbicata, seseornag harus memperhatikan tiga hal antara lain berbicara digunakan proses pelayanan, berbicara digunakan untuk proses sosialisasi, dan berbicara digunakan dengan keyakinan bahwa yang disampaikan adalah benar dan tepat (Nunan, 2015). Dengan demikian, disimpulkan bahwa berbicara merupakan proses seseorang menyampaikan pesan kepada orang lain dengan cara-cara yang tepat dan terjadi interaksi dua arah. Dalam pembelajaran berbicara, setiap siswa diajarkan untuk memahami cara memberikan respon yang baik ataupun menyampaikan pesan sehingga lawan bicara dapat mengerti informasi yang disampaikan. Dalam penelitian ini, konsep pembelajaran berbicara diarahkan pada keterampilan bahasa Inggris untuk mencapai tujuan pembelajaran bahasa Inggris dengan tujuan khusus. Bagi mahasiswa Jurusan Teknik Mesin, pembelajaran berbicara menjadi 
menyenangkan ketika media belajar yang digunakan memberikan stimulus terhadap mahasiswa untuk belajar.

\section{Penilaian Keterampilan Berbicara Bahasa Inggris}

Bachman dan Palmer (2010) mengemukakan bahwa siswa harus menunjukkan kemahiran bahasa melalui tes kinerja. Tugas-tugas yang digunakan dalam penilaian semacam itu harus memungkinkan siswa untuk berbicara, berpartisipasi dalam percakapan, atau berkomunikasi dalam konteks lain yang ada dalam kehidupan nyata. Dalam hal tugas yang sesuai untuk siswa sekolah dasar, Mckay (2006) menggambarkan dua jenis: 1) kegiatan berbicara murni, seperti bercerita, bercerita, pembicaraan gambar, tugas kategorisasi, presentasi lisan, dan genre lain yang hanya berbicara 2) kegiatan yang mendengarkan keterampilan dan keterampilan berbicara digabungkan bersama, seperti wawancara lisan dan tugas tanya jawab. Skala penilaian, kadang-kadang disebut sebagai skor rubrik atau skala kecakapan (Fulcher, 2003) umumnya digunakan untuk mengukur kinerja siswa pada penilaian bahasa lisan otentik. Mengenai kriteria penilaian untuk kemahiran berbahasa Inggris tertulis, Weigle (2002) mempresentasikan pandangannya pada dua jenis skala penilaian, yaitu 1) skala peringkat holistik dan 2) skala peringkat analitik. Definisi penilaian holistik yang diberikan oleh Cooper (1977 yang dikutip dalam Fulcher, 2003) adalah: prosedur apa pun yang berhenti menyebutkan fitur linguistik, retorika, atau informasi dari sepotong tulisan. Beberapa prosedur holistik dapat menentukan sejumlah fitur tertentu dan bahkan mengharuskan setiap fitur dinilai secara terpisah, tetapi pembaca tidak pernah diharuskan untuk berhenti dan menghitung atau menghitung insiden fitur tersebut.

\section{METODE PENELITIAN}

Penelitian ini merupakan penelitian kualitatif dan kuantitatif dengan metode penelitian tindakan (action research). Prosedur pelaksanaan penelitian tindakan ini menggunakan konsep teori dari Kemmis dan McTaggart. Tahapan yang dilakukan adalah identifikasi masalah awal, perencanaan tindakan, pelaksanaan tindakan, observasi atau pengamatan hasil tindakan, dan refleksi tindakan. Ketika hasil refleksi tindakan belum menunjukkan hasil yang sesuai dengan ketetapan dalam penelitian maka dilanjutkan pada siklus berikutnya. Dalam penelitian ini, ada tiga siklus yang sudah dilaksanaka. Sampel penelitian adalah mahasiswa Jurusan Teknik Mesin Politeknik Negeri Jakarta semester II tahun ajaran 2018/2019 sebanyak 30 mahasiswa. Teknik pengumpulan data yang adalah tes, observasi, dan dokumentasi. Proses validitas data penelitian adalah kredibilitas, transferabilitas, dependabilitas dan konfirmabilitas. Untuk meningkatkan keabsahan data temuan, peneliti melibatkan kolaborator. Penelitian tindakan ini dikatakan berhasil ketika nilai rata-rata mencapai 80 dan mahasiswa sudah mendapatkan nilai paling kecil 70 sebanyak $90 \%$.

\section{HASIL DAN PEMBAHASAN}

Proses Pembelajaran Berbicara Bahasa Inggris Melalui Media Belajar Film

Proses pembelajaran dapat dilihat dari hasil kegiatan tindakan selama proses belajar mengajar di kelas. Proses tindakan terdiri atas tiga siklus. Analisis data proses pembelajaran dilihat dari hasil pengamatan aktivitas mahasiswa dan aktivitas dosen dan catatan harian mahasiswa.

Proses pembelajaran yang dilakukan menggunakan film pada tindakan siklus pertama sampai ketiga adalah;

a. Dosen menyediakan beberapa film documenter yang memiliki nilai 
karakter baik dan sesuai dengan pembelajaran yang dibahas.

b. Dosen memutar film sebanyak dua kali.

c. Mahasiswa diminta untuk diskusi dan atau membuat draf untuk menyampaikan isi film.

d. Mahasiswa maju satu per satu ataupun berkelompok untuk menyampaikan ataupun mempresentasikan isi film yang telah ditonton.

e. Mahasiswa lain memberikan feedback atau penilaian terhadap hasil presentasi rekannya.

f. Dosen juga melakukan kegiatan berdialog sebanyak dua atau tiga orang mahasiswa untuk membahas tentang isi film.

g. Dosen memberikan nilai kepada mahasiswa tentang hasil dialog ataupun presentasi.

Implementasi film selama belajar di kelas menunjukkan perubahan perilaku dalam belajar. Pada saat belajar berdialog ataupun presentasi, mahasiswa sangat antusias dan memiliki keinginan belajar. Proses pembelajaran setiap siklus terdiri dari tiga pertemuan. Berikut grafik hasil akhir presentase terhadap pengamatan aktivitas dosen dari siklus pertama sampai ketiga.

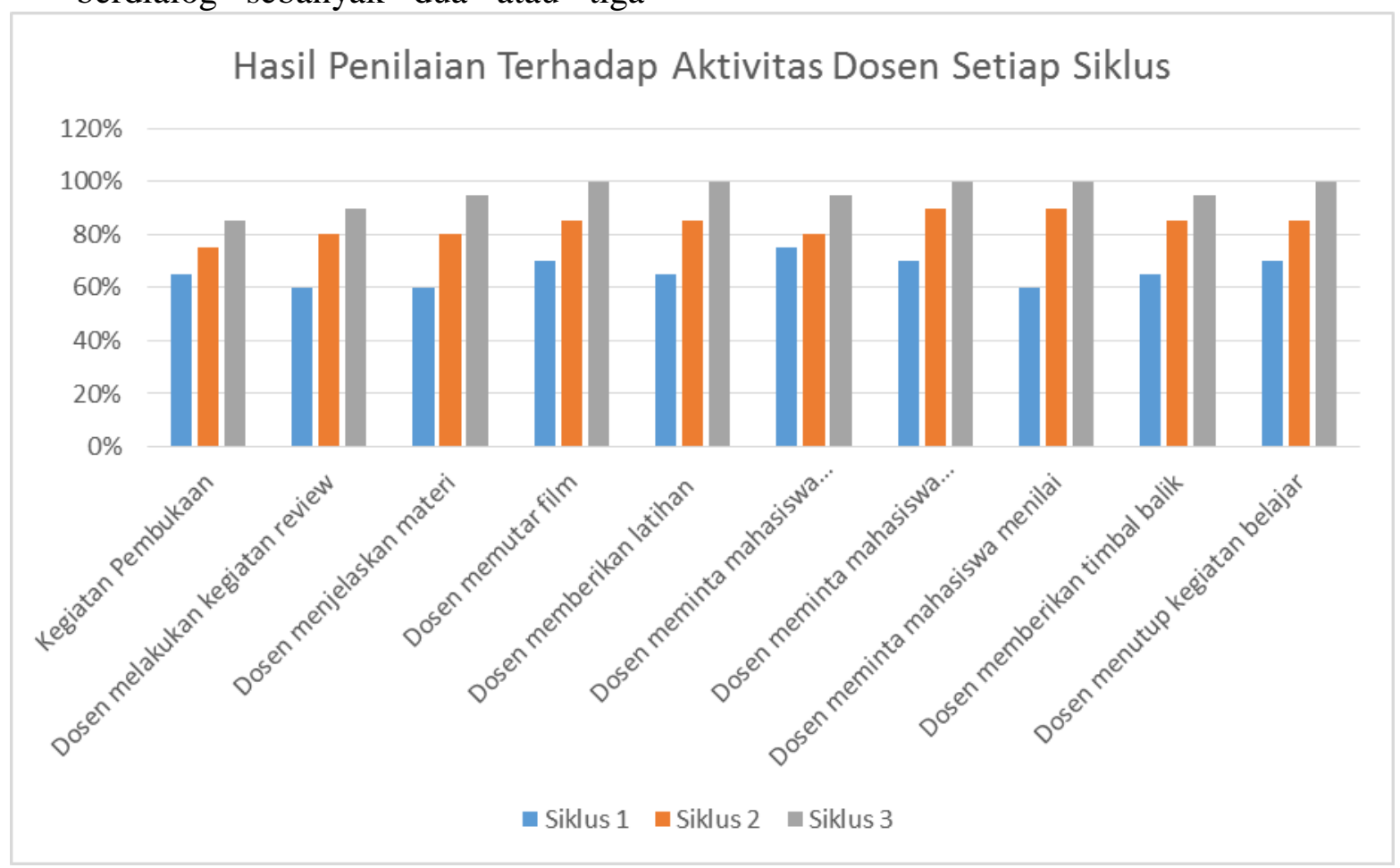

Grafik 1. Hasil Pengamatan Terhadap Aktivitas Dosen

Aktivitas pertama adalah kegiatan pembuka yang dibuka dengan salam dan doa sudah dinilai signifikan dengan persentase tertinggi 85\%. Aktivitas kedua adalah kegiatan review baik materi yang sudah dibahas sudah mencapai persentase 90\% diakhir siklus. Aktivitas ketiga adalah dosen menjelaskan materi yang didskusikan dengan jelas dan tepat mencapai persentase sebesar 95\%. Aktivitas keempat adalah dosen memutar film sudah mencapai persentase 100\%.
Aktivitas kelima adalah dosen memberikan latihan dengan bertahap mencapai persentase sebesar 100\%. Aktivitas keenam adalah dosen meminta mahasiswa melakukan latihan berdialog mencapai persentase sebesar 95\%. Aktivitas ketujuh adalah dosen meminta mahasiswa presentasi mencapai persentase 100\%. Aktivitas kedelapan adalah dosen memberikan timbal balik untuk menilai hasil latihan mahasiswa mencapai persentase sebesar 95\%. 
Aktivitas kesepuluh adalah dosen menutup kegiatan belajar dengan mamaparkan hasil belajar yang sudah dilakukan mencapai persentase sebesar $100 \%$.
Dari paparan tersebut diketahui bahwa pada siklu ketiga setiap aktivitas dosen sudah sangat baik dan optimal. Berikut ini hasil persentase aktivitas mahasiswa pada siklus pertama sampai siklus ketiga,

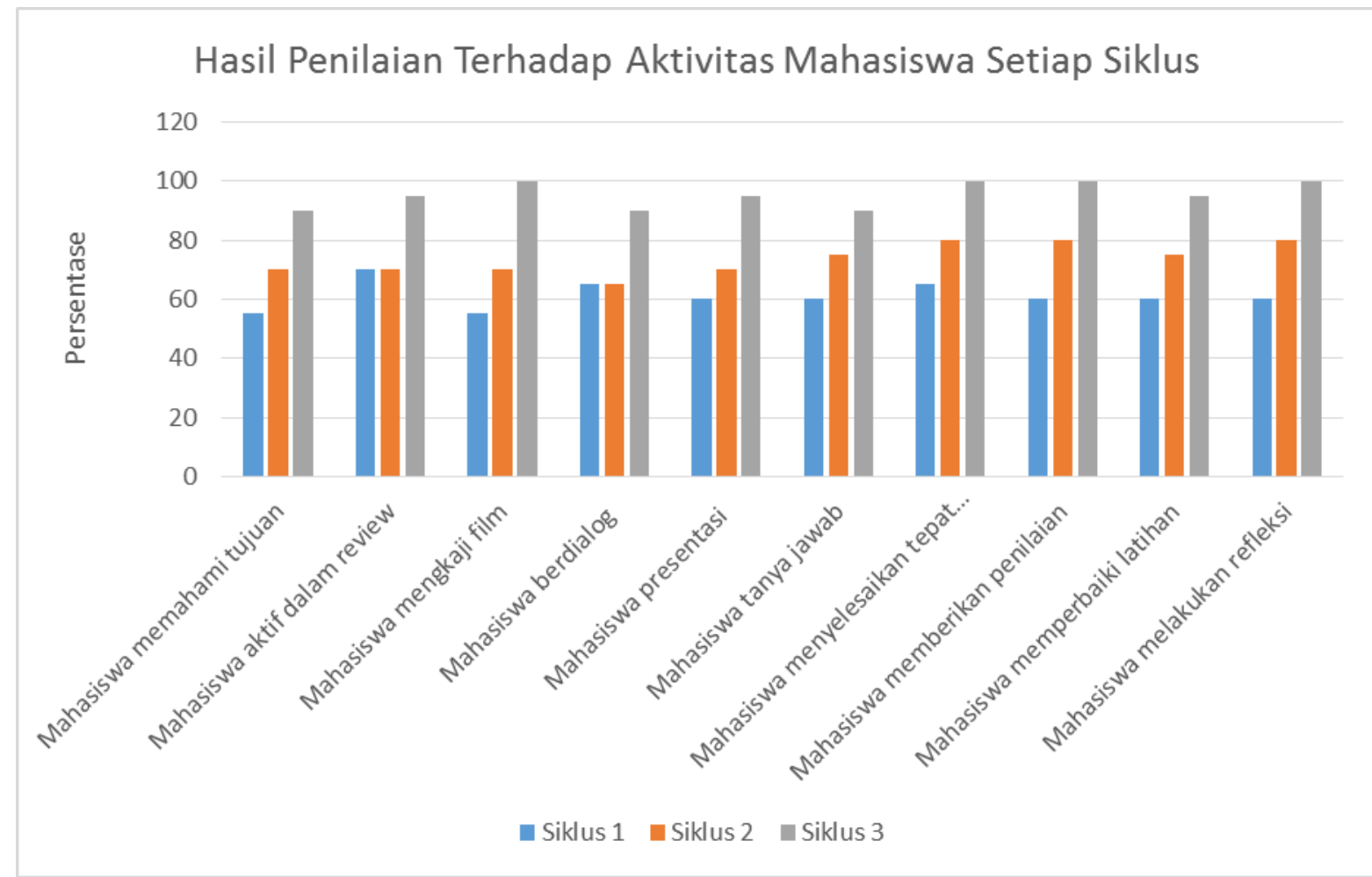

Grafik 2. Hasil Pengamatan Terhadap Aktivitas Mahasiswa

Grafik 2 menunjukkan hasil penilaian dalam bentuk persentase akhir. Aktivitas pertama adalah mahasiswa memahami tujuan yang telah dijelaskan oleh dosen di awal kegiatan telah mencapai persentase sebesar 90\%. Aktivitas kedua adalah mahasiswa aktif dalam review mencapai persentase sebesar 95\%. Dalam hal ini mahasiswa seringkali terlibat tanya jawab ketika dosen melakukan kegiatan review. Aktivitas ketiga adalah mahasiswa mengkaji film mencapai persentase sebesar 100\%. Mahasiswa setelah menonton film diskusi dengan kelompok atau rekannya untuk mengkaji isi materi film. Aktivitas keempat adalah mahasiswa melakukan praktek dialog dengan rekannya mencapai persentase sebesar 90\%. Aktivitas kelima adalah mahasiswa persentasi hasil isi film mencapai persentase sebesar 95\%. Aktivitas keenam adalah mahasiswa melakukan kegiatan tanya jawab dengan dosen ataupun sesama mahasiswa mencapai persentase sebesar 90\%. Aktivitas ketujuh adalah mahasiswa menyelesaikan latihan tepat waktu sesuai dengan instruksi yang dosen berikan mencapai persentase sebesar 100\%. Aktivitas kedelapan adalah mahasiswa memberikan penilaian dialog ataupun presentasi mencapai presentase sebesar 100\%. Aktivitas kesembilan adalah mahasiswa mempebaiki latihan yang telah diberikan penilaian oleh sesama rekan ataupun dosen mencapai persentase sebesar 95\%. Aktivitas kesepuluh adalah mahasiswa melakukan refleksi kegiatan pembelajaran yang dilakukan mencapai persentase sebesar 100\%. Dengan demikian dapat disimpulkan bahwa aktivitas mahasiswa sudah sangat optimal dalam belajar berbicara bahasa Inggris menggunakan film. 
Sedangkan hasil analisis catatan harian dan dokumen observasi terhadap proses tindakan yang dilakukan sebanyak tiga siklus menununjukkan perubahan tanggapan yang baik terhadap penggunaan film. Hal ini disebabkan karena film menjadi bagian dari kehidupan sehari-hari mahasiswa yang selalu digunakan oleh mahasiswa. Film berupa video pendek seringkali ditonton melalui telepon pintar mereka dalam kehidupan sehari-hari. Tanggapan positif mahasiswa terhadap penggunaan film menyimpulkan bahwa media belajar yang tepat bagi mahasiswa adalah media belajar yang erat dengan kehidupan sehari-hari. Apalagi setiap mahasiswa memiliki telepon pintar dan hal tersebut bisa dimanfaatkan untuk proses pembelajaran. Berikut ini hasil persentase tanggapan catatan harian mahasiswa terhadap implementasi film dalam pembelajaran berbicara bahasa Inggris.

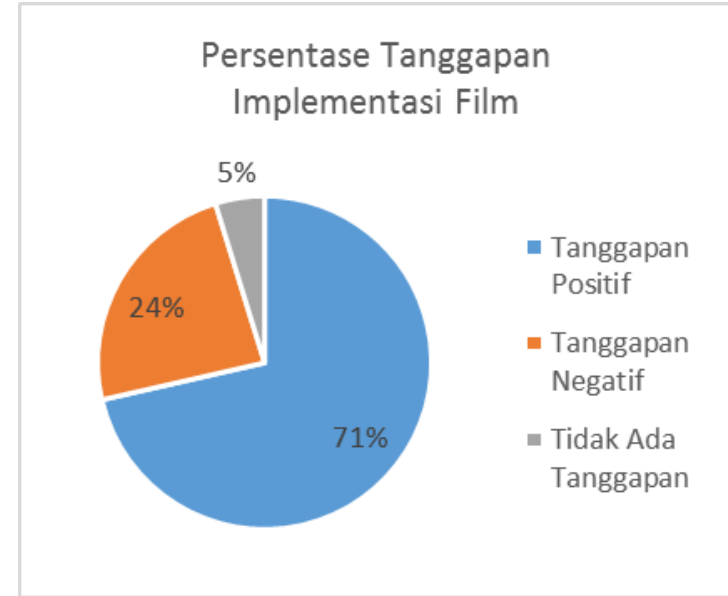

Grafik 3. Tanggapan Mahasiswa Terhadap Implementasi Film Dalam Pembelajaran Berbicara Bahasa Inggris

Grafik 3 menunjukkan tingkat persentase yang besar terhadap implementasi film. Mahasiswa sangat senang menggunakan film selama belajar berbicara bahasa Inggris.

\section{Hasil Peningkatan Keterampilan Berbicara Bahasa Inggris Melalui Media Belajar Film}

Keberhasilan implementasi film juga dapat dilihat dari hasi tes pre-test dan post-test. Berikut hasil perbandingan tes yang diambil dari siklus ketiga

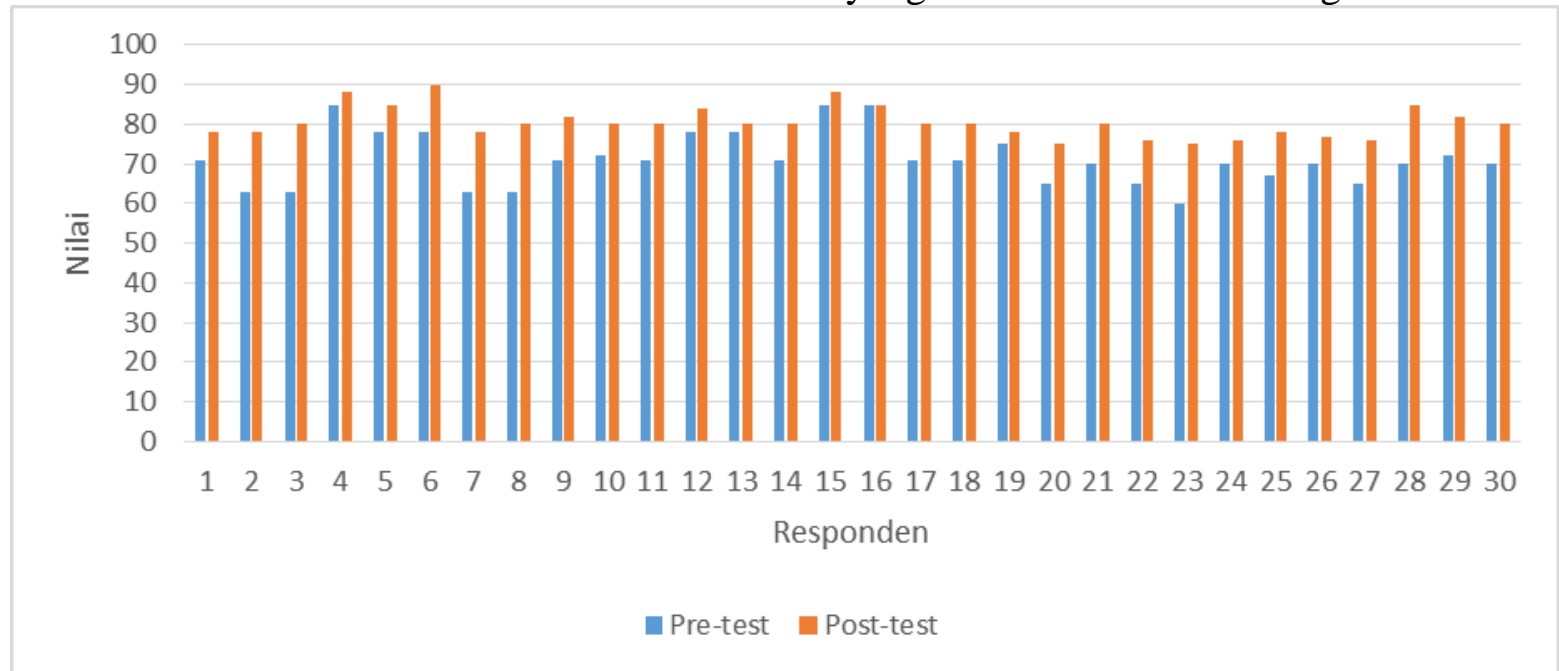

Grafik 4. Hasil Pre-test dan Post-test

Grafik 4 menunjukkan hasil pretest yang merupakan hasil posttest pada siklus kedua. Nilai tertinggi pretest adalah 85 dan nilai terendah adalah 60 . Sedangkan nilai tertinggi posttest adalah 90 dan nilai terendah adalah 75 . Perkembangan nilai yang telah dipaparkan pada graik 4 sangat baik dan setiap mahasiswa mengalami meningkatan nilai tes. Artinya dapat disimpulkan bahwa tingkat kemampuan berbicara bahasa Inggris mengalami peningkatan yang cukup baik dan optimal. 
Mahasiswa yang mendapatkan nilai sama dengan dan di atas 80 sebesar 63,3\%. Sedangkan mahasiswa yang mendapat nilai pada rentang 70 sampai 79 mendapatkan persentase sebesar 36,7\%.

Di Eropa banyak program televisi dan film diimpor dari negara-negara berbahasa asing. Tiga pendekatan adaptasi utama untuk transfer bahasa menggunakan karya audio-visual hidup berdampingan di Eropa: subtitle, sulih suara lip-sync (atau hanya dubbing) dan voice-over. Praktik-praktik ini digunakan untuk menerjemahkan karya audio-visual asing ke dalam bahasa nasional. Pembelajaran bahasa melalui menonton program subtitle biasanya terjadi dalam konteks informal. Namun, beberapa penelitian menunjukkan bahwa ada minat yang meningkat di kalangan guru bahasa asing untuk menggunakan kutipan dari program televisi seperti program berita (Vann, 1996), opera sabun (Grant, 1996) dan program musik (Mason, 1997) untuk tujuan pendidikan. Akan menarik untuk mengidentifikasi dan menganalisis praktik terbaik yang ada dalam penggunaan subtitling sebagai alat untuk mempromosikan penguasaan bahasa asing. Penting juga untuk mempromosikan kesadaran akan manfaat dari subtitle dibandingkan sulih suara, terkait dengan pembelajaran bahasa dan pengembangan keterampilan kognitif (Almeida \& Costa, 2014).

\section{KESIMPULAN DAN SARAN \\ Kesimpulan}

Dari hasil analisis data disimpulkan bahwa kemampuan berbicra mahasiswa sudah mengalami peningkatan yang cukup optimal. Selama proses pembelajaran yang dilakukan dari siklus pertama sampai siklus ketiga juga terlihat aktivitas yang terus meningkat. Selama menonton film mahasiswa sangat termotivasi dan antusia dalam membuat dialog ataupun mempresentasikan isi film. Mahasiswa juga mengalami peningkatan nilai dari pretest ke posttest. Nilai rata- rata dari siklus pertama adalah 62.2. Nilai rata-rata siklus kedua sebesar adalah 71.2. Nilai rata-rata siklus ketiga adalah 80.5

\section{Saran}

Hasil penelitian ini masioh terbatas pada penggunaan film untuk pembelajaran keterampilan berbicara bahasa Inggris. Padahal jika diintegrasikan dengan keterampilan menulis sangat baik. Hal ini disebabkan karena menulis membutuhkan konsep belajar menyenangkan. Dari hasil penelitian ini berimplikasi pada penggunaan media belajar yang memanfaatkan teknologi. Dosen dapat menggunakan hasil penelitian ini untuk memodifikasi media belajar film untuk proses pembelajaran keterampilan berbicara bahasa Inggris.

\section{DAFTAR PUSTAKA}

Almeida, P. A., \& Costa, P. D. (2014). Foreign Language Acquisition: The Role of Subtitling. Procedia - Social and Behavioral Sciences, 141, 12341238.

https://doi.org/10.1016/J.SBSPRO.201 4.05.212

Bajrami, L., \& Ismaili, M. (2016). The Role of Video Materials in EFL Classrooms. Procedia - Social and Behavioral Sciences, 232, 502-506. https://doi.org/10.1016/J.SBSPRO.201 6.10 .068

Bonsignori, V. (2018). Using films and TV series for ESP teaching: A multimodal perspective. System, 77, 58-69.

https://doi.org/10.1016/J.SYSTEM.201 8.01.005

Brown, S. K. (2010). Popular films in the EFL classroom: Study of methodology. Procedia - Social and Behavioral Sciences, 3, 45-54. https://doi.org/10.1016/J.SBSPRO.201 $\underline{0.07 .011}$ 
Hinkel, E. (2018). Teaching Speaking in Integrated-Skills Classes. In The TESOL Encyclopedia of English Language Teaching (pp. 1-6). Hoboken, NJ, USA: John Wiley \& Sons, Inc. https://doi.org/10.1002/978111878423 5.eelt0256

Kitagaki, I. (2013). Effect of English Short Sentences Memorization on the Speaking Skill and the E-learning of English. Procedia - Social and Behavioral Sciences, 103, 348-351. https://doi.org/10.1016/J.SBSPRO.201 3.10.343

meinawati, euis. (2015). Improving Students’ Academic Paragraph Writing Through Film and Streaming Media. Retrieved from https://www.academia.edu/16529985/I mproving_Students_Academic_Paragr aph_Writing_Through_Film_and_Stre aming_Media

Nunan, D. (2015). Teaching English to Speakers of Other Languages: An Introduction. London \& New York: Routledge.

Richards, J. C. (2008). Teaching Listening and Speaking From Theory to Practice. Cambridge: Cambridge University Press.

Richards, J. C., \& Renandya, W. A. (2002). Methodology in Language Teaching An Anthodology of Current Practice. Cambridge: Cambridge University Press. 
